\title{
Preparation of biological samples containing both metallic and organic structures for SEM
}

\author{
Preparo de amostras biológicas para MEV contendo estruturas orgânicas e metálicas \\ Fernando Vacilotto Gomes ${ }^{1}$, Carlos Eduardo Baraldi², Deise Ponzoni ${ }^{3}$, \\ Marília Gerhardt de Oliveira ${ }^{4}$, Edela Puricelli ${ }^{5}$ \\ ${ }^{1}$ Especialista em CTBMF pela PUC-RS. \\ Mestre em Clínica Odontológica/CTBMF pela UFRGS. \\ ${ }^{2}$ Doutor em Odontologia pela PUC-RS \\ Prof Adjunto da Faculdade de Odontologia da UFRGS. \\ ${ }^{3}$ Doutora em Odontologia pela PUC-RS \\ Prof ${ }^{a}$ Adjunta da Faculdade de Odontologia da UFRGS. \\ ${ }^{4}$ Doutora em Estomatologia Clínica PUC-RS \\ CTBMF do Hospital Cristo Redentor - Grupo Hospitalar Conceição do Ministério da Saúde - Brasil \\ Membro Titular da Academia Brasileira de Odontologia - cadeira 77 \\ ${ }^{5}$ Doutora em Medizinische Fakultat pela Universitat Dusseldorf, Alemanha \\ Professora Titular da UFRGS
}

\begin{abstract}
Objective: results of preclinical studies depend on high-quality sample preparation, which enables proper handling of specimens for observation and analysis with the desired methods. The aim of this paper is to describe a step-by-step method for preparation of bone tissue specimens containing metallic implants for scanning electron microscopy (SEM). Methodology: eight rabbit bone specimens containing one osseointegrated implant each were fixated in 10\% neutral buffered formalin, dehydrated, sectioned, and embedded in thermosetting resin. The specimens were then sanded, polished, and metal-coated for SEM analysis. Results: the method achieved satisfactory specimen surface smoothness, containing no cracks or other artifacts, enabling morphological and chemical analysis by means of SEM and energy-dispersive X-ray spectroscopy (EDS). Conclusion: this method for preparation of animal tissue samples containing both organic and metal components produced specimens amenable to SEM analysis with excellent image quality, enabling assessment of the bone-implant interface, measurement of bone-implant contact, and quantification of bone formation.

Key-words: Dental Implants. Microscopy Electron Scanning. Methodology. Dentistry.
\end{abstract}

\begin{abstract}
Resumo
Objetivo: o resultado das pesquisas pré-clínicas dependem da elevada qualidade de preparo amostral, possibilitando um adequado manejo das peças para a observação nos mais diversos tipos de metodologia. $\mathrm{O}$ objetivo foi apresentar detalhadamente um método diferenciado para preparo de amostras de tecido-ósseo contendo implantes metálicos para Microscopia Eletrônica de Varredura, apresentando os passos para obtenção das peças. Metodologia: oito peças ósseas de modelo experimental coelho contendo um implante osseointegrável foram fixadas por 72 horas em formol $10 \%$ neutro tamponado. A seguir, procedeu-se sua secagem, corte e inclusão em resina termopolimerizável. Posteriormente, realizou-se um processo de lixamento sequencial, polimento e metalização para avaliação por meio de MEV. Resultados: as superfícies obtidas por meio desta metodologia demonstraram lisura superficial e ausência de trincas ou outros artefatos. Permitiu análise morfológica e química por meio de MEV/EDS. Conclusão: por meio desta metodologia, obteve-se amostras contendo componente orgânico e metálico, passíveis de análise por MEV em modelo experimental animal, com grande qualidade de imagem para estudo da interface osso-implante, medição do contato entre estas superfícies e avaliação da área de neoformação óssea.

Palavras-chave: Implantes dentários. Microscopia eletrônica de varredura. Metodologia. Odontologia.
\end{abstract}

\section{INTRODUCTION}

Technological advancements in implant dentistry for orofacial rehabilitation have brought about a need for constant assessment of the biological aspects of union between bone and biomaterials ${ }^{1-5}$. Scanning electron microscopy (SEM) is an imaging modality that enables visu-

Correspondência / Correspondence: Fernando V Gomes. Avenida Independência 1087/303 90035-077 Porto Alegre, RS, Brasil. +55 (51) 3377-8103.fernandovg2005@yahoo.com.br alization of the surface morphology of biomaterials and tissues, thus providing quantitative and qualitative data for assessment of implant outcomes ${ }^{4,6-8}$.

SEM can also serve as a quick source of information on chemical elements present in solid specimens. Current SEM systems provide magnifications of up to $300,000 x$, maintaining depth of field for observation of coarse surfaces and high image definition in the 1 to 5 nanometer spectrum. Energy-dispersive X-ray spectroscopy (EDS) 
Fernando Vacilotto Gomes, et al.

mode, available on some systems, enables identification of the chemical composition of substances present at certain points on the specimen surface ${ }^{6,8}$.

SEM is mainly used for surface examination of organic or inorganic samples, as well as assessment of their chemical components. SEM research is underway in fields of dental science and practice as varied as oral and maxillofacial surgery ${ }^{2}$, orthodontics ${ }^{5,7}$, dental materials ${ }^{4,7}$, implant dentistry ${ }^{9,10}$, and endodontics ${ }^{11}$. Its advantages include high magnification capabilities (nanometer-scale imagin) and precise chemical evaluation. Furthermore, SEM enables surface examination of three-dimensional materials in a wide range of positions and orientations, unlike transmission electron microscopy or optical (light) microscopy, which are only capable of two-dimensional imaging 6,8 .

Different methods for the preparation of samples for SEM were described, each one producing certain characteristics on resulting images. One method involves simply a shallow cut across the bone-and implant-containing specimen, with no further refinements that might enable more thorough assessment and measurement of the exposed area ${ }^{2}$. A different method, used for preparation of implants and abutments, involved gentle cleansing in an ultrasonic cleaner followed by placement onto an inert vinyl surface for visualization ${ }^{12}$. This preparation enabled adequate analysis, but the specimens used in the study did not contain any organic tissue. Another proposed method involved stressing of implants in a testing machine until fracture, followed by direct placement into the electron microscope system. These methods are not inapplicable to samples containing organic tissue ${ }^{13}$. A recent study used a method involving embedding of specimens in thermochemically cured resin to facilitate lengthwise sectioning and sample preparation ${ }^{14}$.

The objective of this paper is to describe a method of preparation of samples for scanning electron microscopy and later assessment of interactions at the bone-implant interface in experimental animal models.

\section{MATERIALS AND METHODS}

This study was approved by the Hospital de Clínicas de Porto Alegre Animal Research Ethics Committee (CEUA/HCPA, protocol no. 12-0112, May 2012). All study procedures were conducted in compliance with the Brazilian Ethical Principles for Animal Experimentation, as set forth in Law 11.794 of 8 October 2008 (the Arouca Act), and the Ethical Principles of Experimental Research established by the Brazilian Society for Laboratory Animal Science (formerly the Brazilian College of Animal Testing), respecting international guidelines for animal experimentation.

Eight specimens obtained from rabbits subjected to surgical extraction of the mandibular central incisor and osseointegrated implant placement were prepared for SEM analysis.

The preparation protocol was as follows:
1. Exposure and preparation of the implant-containing portion of the specimen (Figure 1);

2. Dehydration in a graded ethanol series (50\%, $60 \%, 70 \%, 80 \%, 90 \%$ );

3. Further dehydration for 14 days over silica gel in a vacuum desiccator (Kartell ${ }^{\circledR} 250 \mathrm{~mm}$, Milan, Italy).

4. Placement of specimens into individual, labeled capsules and embedding in SEM-specific resin (EMBed-812 Embedding Kit. EMSDIASUM ${ }^{\circledR}$, Hatfield, Pennsylvania, USA);

5. Heat curing in a conventional cooking oven (Diplomata Fischer ${ }^{\oplus}$, Brusque, Santa Catarina, Brazil) for 48 hours at $60^{\circ} \mathrm{C}$.

6. Embedded specimens were removed from their capsules and attached to the cutting jig of a precision saw (Logitech AXL1 Annular Saw, Materials Technologists \& Engineers, Glasgow, Scotland) with quick-set adhesive (Araldite ${ }^{\circledast}$ Brascola Ltda, Joinville, SC, Brazil; working time 3 min, setting time $8 \mathrm{~h}$ ).

7. After curing, the jig was attached to the saw for sectioning at $1000 \mathrm{rpm}$ under constant irrigation with a solution of antioxidant/coolant additive (PanTec Aditom $^{\circledast}$, Panambra, REDsul Equipamentos Industriais, Rio Grande do Sul, Brazil) in water at a ratio of $17 \mathrm{~mL}$ additive to $5 L$ water. Specimens were bisected lengthwise so as to expose the bone-implant interface longitudinally as well as the cortical and basal bone of the mandible (Figure 2). Only one of the specimen halves thus produced was used for analysis, as, due to the chosen sectioning method, the other half of the specimen was inevitably destroyed during preparation.

8 . The resulting specimens were then sanded sequentially with 220-, 320-, 400-, and 600-grit wet/dry sanding discs (3M Sumaré, São Paulo, Brazil) fitted to a single-speed (250 rpm), twin-platen rotary polishing machine (LaboPol-1, Struers A/S DK-2750, Ballerup, Denmark). Finally, a 1200-grit disc was used to partly clean the residue from the rougher-grit sanding process.

9. After copious rinsing with deionized water, the eight specimens were polished. This stage was performed with a twin-platen metallographic polishing machine (LaboPol-25, Struers, Ballerup, Denmark), using a combination of felt pads and 1-micron alumina solution, followed by 0.25 -micron solution to remove any residue from the sanding process and address any scratches on the implant surface. Finally, specimens were once again dehydrated over silica gel in a vacuum desiccator for 2 weeks and sputter-coated with gold (BAL-TEC SCD 050 Sputter Coater, Capovani Brothers Inc., Scotia, New York, USA) (Figure 3).

SEM analysis was carried out in a Philips model XL 30 FEG EDX system (Philips, Eindhoven, the Netherlands), over a wide range of magnifications (Figure 4), from 25x, through 50x and 250x to 300x, for assessment of the bone-implant interface and EDS analysis of the chemical composition of neoformed tissue in the bone-implant region. 
Figure 1. Osteotomy of the left anterior portion of a rabbit mandible to produce an implant-containing bone specimen.

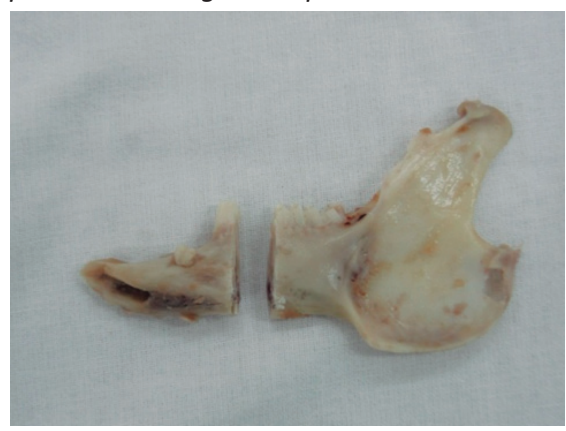

Figure 3. Specimen after sputter-coating and completion of the preparation protocol.

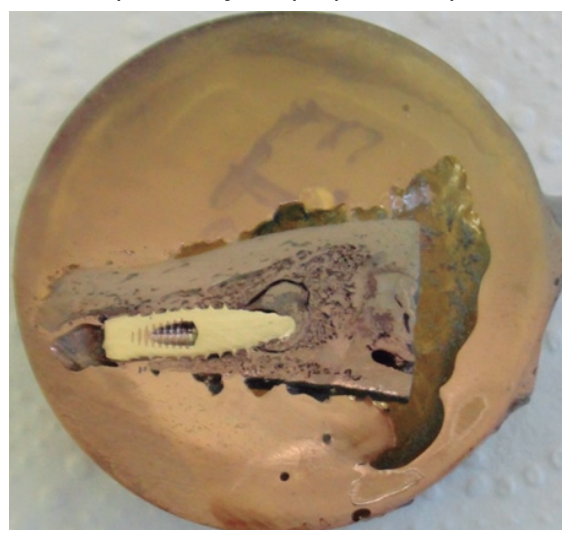

\section{RESULTS}

To the naked eye, all samples presented clean and devoid of deep surface scratches after preparation. This outcome facilitates sputter-coating, an essential stage of SEM specimen preparation, by providing an adequately smooth and interference-free surface.

The implant and surrounding tissues were visualized longitudinally, facilitating the surface scanning process that forms the mainstay of SEM analysis. The entire area of bone-implant contact could be assessed, at all three thirds of the implanted bone (apical, middle, and cervical) (Figure 5).

The quality of secondary-electron (SE) and backscattered-electron (BSE) images was sufficient for assessment of the bone-implant interface at all tested magnifications, enabling observation of the cortical and medullary bone of the mandible as well as of the close relationship between the organic tissues and metallic implant.

\section{DISCUSSION}

In sharing our experience with this sample preparation method, we sought to make it available to researchers of all areas who might require a protocol for SEM analysis of specimens containing both organic tis-
Figure 2. Specimen immediately after sectioning.

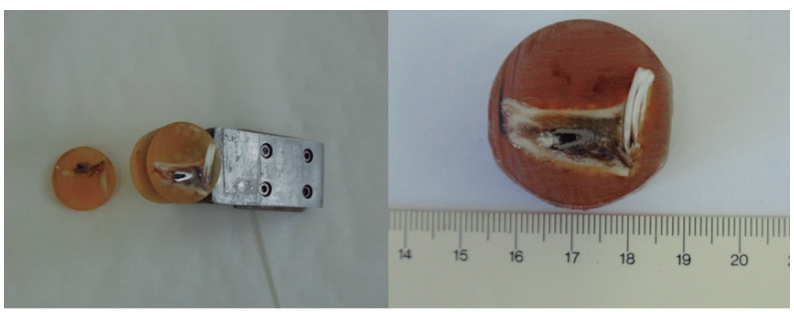

Figure 4. SEM image of the specimen (BSE mode, 250x magnification). Medullary and cortical bone is clearly visible, as is the contour of the whole implant thread, enabling a wide range of measurements.

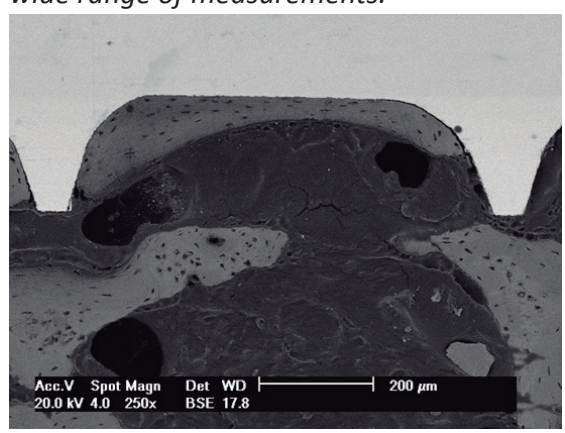

Figure 5. Comparison of SE and BSE images under 50x magnification. There is a noticeable difference in image quality.

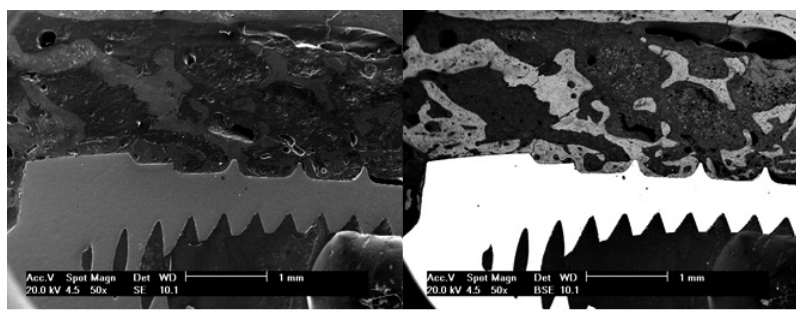

sue and a metallic component. Clearly, the care taken during sample preparation is directly proportional to image quality and, consequently, to the quality of the measurements of interest to the study at hand. The preparation method used herein enabled assessment of the bone-implant contact (BIC) surface and of the neoformed bone area (BA). Thus far, light microscopy was the only imaging modality to enable use of such quantitative methods $3,15,16$.

The difference between SEM and conventional, light microscopy-based histology or histomorphometry lies not only in the available range of magnification, but also in sample preparation requirements. Specimens meant for SEM analysis have unique preparation demands, including surface etching or grinding, polishing, 
and gold or carbon coating. Dehydration over silica gel in a vacuum desiccator ensures complete removal of any traces of formalin from porous bone tissue and from the implant structure, enabling resin embedding of the entire specimen. Samples were then sputter-coated with gold, a common choice of material for this purpose, so as to confer conductivity to the surface of otherwise nonconductive biological tissues. The purpose of coating is to make specimens conductive and thus ensure high-resolution SEM images. Careful control of the thickness of the metal coating is required to prevent image artifacts that might conceal the actual surface of the specimen 6.

SEM provides two basic modes for assessment of the sample surface: secondary-electron mode (SE) and backscattering-electron mode (BSE). In SE mode, lowenergy electrons $(<50 \mathrm{eV})$ are used to obtain high-resolution (3-5 nm) images; contrast is mostly provided by specimen relief. This is the most common SEM imaging mode, as it enables greater magnification without loss of image quality. In BSE mode, as the high-energy backscattered electrons are the results of simple elastic collision, they are ejected from the superficial layers of the specimen. Therefore, this mode provides comparatively little depth information due to the penetration depth of the electron beam. BSE images provide different types of information depending on the type of contrast displayed: in addition to a topographic image (contrast as the result of surface relief), BSE images display compositional contrast, which is a function of the atomic numbers of the different elements present in the specimen ${ }^{6}$.

In a previous study ${ }^{2,14}$ rabbits were subjected to osseointegrated implant placement in the tibia followed by low-level laser therapy exposure and SEM and microRaman spectroscopy assessment of bone-implant specimens. In this investigation, samples were sectioned without prior resin embedding. Although it enables visualization, this technique differs from the method reported in our study. Our technique ensures that the specimen remains in the same position throughout sectioning, preparation (sanding and polishing) and visualization, as specimens are kept at similar heights and orientations during placement into the microscope system. This yields clear, easily distinguishable images of the bone and implant surfaces, enabling measurement or any other assessments of a topographic nature.

Another similar method was described in a recent study of implant placement in the pig calvaria ${ }^{14}$, in which samples were resin-embedded, sectioned, and polished to enable high-definition imaging. With this technique, resin embedding is mandatory, which ensures the quality of later sample preparation.

An adjunctive technique that can be employed during SEM analysis is EDS, which consists of X-ray irradiation of the sample to elucidate the chemical composition of its surface. Data contained in the X-ray spectrum can be used to obtain qualitative and quantitative information on sample composition at the microscopic level
6. EDS analysis needs no further specimen preparation other than that required for SEM.

Resin embedding of bone-implant samples plays an essential role in ensuring good specimen yield. Specimen placement within the resin matrix may facilitate or hinder sectioning. Therefore, in this study, specimens were oriented within their cylindrical embedding capsules so as to enable longitudinal sectioning, which would facilitate maximal visualization of the bone-implant interface. In the rabbit model, dental implantation occurs in the axial direction, as opposed to the sagittal direction in humans; this should be taken into account to ensure successful sectioning. Therefore, specimen orientation so as to enable longitudinal sectioning also meant that the saw advanced in the occluso-apical direction along the sagittal axis of the specimen during sectioning. This produced specimens with thick cortical bone in the superior portion and good tissue volume in the basal bone. Had specimens been sectioned in the axial direction, the exposed bone tissue would have been from the lateral and medial aspects, yielding a satisfactory bone volume in the medial portion but minimal or nonexistent lateral bone volume due to resorption, as this lateral aspect corresponds to the buccal side of the mandibular bone in humans, and normal rabbit anatomy is conducive to implantation in a more buccal position.

\section{CONCLUSION}

This sample preparation method enabled SEM visualization of biological specimens containing both organic (bone tissue) and metallic (osseointegrated implant) components, with excellent image quality, for assessment of the bone-implant interface, measurement of bone-implant contact, and quantitation of bone neoformation, which were previously only amenable to light microscopy techniques.

\section{Author Disclosure Statement}

No competing financial interests exist.

\section{Financial support}

This study was funded by FIPE-HCPA (Fundo de Incentivo à Pesquisa e Eventos do Hospital das Clínicas de Porto Alegre).

\section{Acknowledgments}

The authors would like to thank Drs Fabrício Poletto Massotti and Luciano Mayer, DDS; Prof. Berenice Anina Dedavid, PhD, Centro de Microscopia e Microanálises (PUCRS); and the staff at the HCPA Animal Experimentation Unit, particularly Dr. Fabíola Schons Meyer, DVM, and Ms. Marta Justina Giotti Cioato, RN.

\section{REFERENCES}

1. CAMPANHA, B.P. et al. Low-level laser therapy for implants without initial stability. Photomed. Laser Surg., Larchmont, v. 28, n. 3, p. 365379, 2010. 
2. LOPES, C.B. et al. Infrared laser photobiomodulation (lambda 830 $\mathrm{nm}$ ) on bone tissue around dental implants: a Raman spectroscopy and scanning electronic microscopy study in rabbits. Photomed. Laser Surg., Larchmont, v. 25, n. 2, p. 96-101, 2007.

3. PEREIRA, C.L. et al. The effect of low-intensity laser therapy on bone healing around titanium implants: a histometric study in rabbits. Int. J. Oral Maxillofac. Implants., Lombard, v. 24, n. 1, p. 47-51, 2009.

4. OTULAKOWSKA, J.; NICHOLSON, J.W. Scanning electron microscopy and energy dispersive $X$-ray study of a recovered dental implant. J. Mater Sci. Mater. Med., Londres, v. 17, n. 3, p. 277-79, 2006.

5. GALLI, C. et al. Effect of surface treatment on cell responses to grades 4 and 5 titanium for orthodontic mini-implants. Am. J. Orthod. Dentofacial Orthop., St. Louis, v. 141, n. 6, p. 705-14, 2012.

6. DEDAVID, B.A.; GOMES, C.I.; MACHADO, G. Microscopia eletrônica de varredura: aplicações e preparação de amostras : materiais poliméricos, metálicos e semicondutores. Porto Alegre: EDIPUCRS, 2007. p.160.

7. BASCHONG, W. et al. Confocal laser scanning microscopy and scanning electron microscopy of tissue Ti-implant interfaces. Micron., Oxford, v. 32, n. 1, p. 33-41, 2001.

8. CHAI, W.L. et al. A review of histomorphometric analysis techniques for assessing implant-soft tissue interface. Biotech.\& Histochem., Baltimore, v. 86, n. 4, p. 242-54, 2011.

9. VAQUERO-AGUILAR, C. et al. Zirconia implant abutments: microstructural analysis. Int. J. Oral Maxillofac. Implants., Lombard, v. 27, n. 4, p. 785-91, 2012
10. DEPPE, H. et al. Per-implant care of ailing implants with the carbon dioxide laser. Int. J. Oral Maxillofac. Implants., Lombard, v. 16, n. 5, p. 659-67, 2001.

11. TIAN, Y. et al. Failure of Fiber Posts after Cementation with Different Adhesives with or without Silanization Investigated by Pullout Tests and Scanning Electron Microscopy. J. Endod., Baltimore, v. 38, n. 9, p. 1279-82, 2012

12. DELLOW, A.G.; DRIESSEN, C.H.; NEL, H.J. Scanning electron microscopy evaluation of the interfacial fit of interchanged components of four dental implant systems. Int. J. Prosthodont., Lombard, v. 10, n. 3, p. 216-21, 1997.

13. SHEMTOV-YONA, K. et al. Effect of Dental Implant Diameter on Fatigue Performance. Part II: Failure Analysis. Clin. Implant. Dent. Relat. Res., Hamilton, v.10, 2012.

14. MEHL, C. et al. Impact of vertical loading on the implant-bone interface. Clin. Implant. Dent. Relat. Res., Hamilton, v. 24, n. 8, p. 949-956, 2012.

15. WEBER, J.B.B. et al. Laser therapy improves healing of bone defects submitted to autologous bone graft. Photomed. Laser Surg., Larchmont, v. 24, n. 1, p. 38-44, 2006.

16. KREISNER, P.E. et al. Histological evaluation of the effect of lowlevel laser on distraction osteogenesis in rabbit mandibles. Med. Oral Patol. Oral Cir. Bucal., Valencia, v. 15, n. 4, p. 616-18, 2010.

Submetido em 07.05.2013;

Aceito em 16.08.2013. 